\title{
Characteristics of a Potyvirus of the Bean Yellow Mosaic Virus Subgroup in Sesbania speciosa Germ Plasm
}

\author{
A. G. Gillaspie, Jr., M. S. Hopkins, and D. L. Pinnow, USDA-ARS, Plant Genetic Resources Conservation Unit, \\ Griffin, GA 30223-1797; and R. L. Jordan, USDA-ARS, Floral and Nursery Plants Research Unit, U. S. National \\ Arboretum, BARC-West, Beltsville, MD 20705-2350
}

\begin{abstract}
Gillaspie, A. G., Jr., Hopkins, M. S., Pinnow, D. L., and Jordan, R. L. 1998. Characteristics of a potyvirus of the bean yellow mosaic virus subgroup in Sesbania speciosa germ plasm. Plant Dis. $82: 807-810$

A plant of Sesbania speciosa with leaf mosaic and distortion symptoms was identified in a germ plasm regeneration plot at Griffin, Georgia. The Sesbania virus produced mild or moderate mosaic symptoms on Glycine max cvs. Bragg and Tracy M, Lupinus albus, Nicotiana benthamiana, Pisum sativum cv. Perfected Wales, Phaseolus vulgaris cvs. Black Turtle, Bountiful, and Pinto, and did not infect N. tabacum. Bean yellow mosaic potyvirus (BYMV) and pea mosaic potyvirus (PMV) do not infect Perfected Wales pea and they produce mosaic, distortion, and necrosis on white lupine. The PMV strain tested produced much more severe symptoms on the three green beans, with top necrosis on Pinto. BYMV produced local latent infection of N. tabacum and BYMV and PMV produced mosaic with distortion on $N$. benthamiana. The Sesbania virus was seed-transmitted at a low rate in S. speciosa. Indirect-enzyme-linked immunosorbent assay tests with a general potyvirus monoclonal antibody and BYMV and white lupine mosaic virus (WLMV) polyclonal antisera were strongly positive. Tests of the Sesbania virus against a monoclonal antibody panel suggests that it is not BYMV or any of the previously described subgroup members, but is a member of the BYMV subgroup. This is the first report of a seedborne BYMV-like virus of Sesbania spp.
\end{abstract}

Plant viruses pose a threat to the acquisition, maintenance, and distribution of crop germ plasm that is the backbone of the National Plant Germplasm System. Seeds of legumes such as peanuts, cowpeas, mung beans, clovers, peas, beans, and faba beans are always suspect, since a number of viruses are known to be seedborne in these crops. Therefore, specialpurpose legume germ plasm (13), including Sesbania, is planted in increase (regeneration) plots, where a close watch is kept for new or exotic viruses. Symptomatic plants are tested by enzyme-linked immunosorbent assay (ELISA) to determine if known seedborne viruses are involved. Infected plants found soon after field planting are typically removed and

Corresponding author: A. G. Gillaspie, Jr. E-mail:s9gg@ars-grin.gov

Mention of a trademark or proprietary product does not constitute a guarantee or warranty of the product by the United States Department of Agriculture and does not imply its approval to the exclusion of other products that may also be available.

Accepted for publication 7 April 1998.

Publication no. D-1998-0515-01R

This article is in the public domain and not copyrightable. It may be freely reprinted with customary crediting of the source. The American Phytopathological Society, 1998. destroyed. Seed lots of crops known, or suspected, to contain exotic seedborne viruses are grown under greenhouse conditions, tested by serology, and only plants testing virus-free are grown for seed production (5).

Sesbania Scop. (ex. Agati Adans., ex. Daubentonia DC.) of the Fabaceae family is a genus containing a number of species of plants that have potential use for fiber, forage, gum, soil improvement (green manure), pulp, firewood, or ornamental purposes in warm climates of the tropics and subtropics. They are valued for their tolerance of soil salinity, heavy soils, and waterlogged soils. The tolerance for water allows it to be used as a cover crop in rice production areas. Sesbania spp. contain annuals as well as perennial shrubs and trees, and are native to Africa, Asia, Australia, and Hawaii. S. speciosa Taubert (PI 321747), originating in Pakistan, was planted in a regeneration plot in Griffin, Georgia, and one plant was observed with mosaic symptoms and distorted leaves.

Prior to this study, the only virus reported to infect Sesbania spp. under natural conditions was Sesbania mosaic virus, which is probably a sobemovirus $(1,16)$. Edwardson (3) lists bean common mosaic (BCMV), bean yellow mosaic (BYMV), peanut mottle (PeMV), passionfruit ringspot, passionfruit woodiness, soybean mosaic, and watermelon mosaic potyviruses among those viruses that have been re- ported to infect Sesbania spp. by artificial inoculation. We report here the identification of a BYMV-like virus infecting $S$. speciosa Taubert. The approach was to use biological and serological tests, including ELISA, with potyvirus-specific polyclonal antisera and with a large panel of potyvirus cross-reactive monoclonal antibodies (MAbs) to compare the isolated potyvirus from a Sesbania sp. to other characterized potyviruses (10). This approach has been used to study other plant potyviruses $(6,8)$.

\section{MATERIALS AND METHODS}

Host range. The following hosts were inoculated with both the Sesbania virus and the pea isolate of BYMV-PV-89 (also referred to as pea mosaic potyvirus [PMV], American Type Culture Collection [ATCC], Rockville, MD): cucumber (Cucumis sativus L.) cv. Chicago Pickling; cowpea (Vigna unguiculata (L.) Walp. subsp. unguiculata) cvs. California Blackeye \#5 and Coronet; eggplant (Solanum melongena L.) cv. Black Beauty; green bean (Phaseolus vulgaris L.) cvs. Black Turtle 2, Black Turtle Soup, Bountiful, Pinto, and Top Crop; lima bean (Phaseolus lunatus L.) cv. Henderson; pea (Pisum sativum L. subsp. sativum) cvs. Dark Skin Perfection, Little Marvel, and Perfected Wales; peanut (Arachis hypogaea L.) cvs. Georgia Red and Florunner; pepper (Capsicum annum L. var. annuum) cv. Hot Hungarian; pumpkin (Cucurbita pepo L.) cv. Early Sugar; squash (Cucurbita pepo L.) cv. Early Golden Summer; soybean (Glycine max (L.) Merr.) cvs. Bragg and Tracy M; tobacco and wild species (Nicotiana glutinosa L.) cvs. TW 58 and TW 59, (Nicotiana tabacum L.) cvs. NC 95 and Burley 21, and (Nicotiana benthamiana Domin) cvs. TW 16 and TW 17; tomato (Lycopersicon lycopersicum (L.) Karsten var. Lycopersicum) cv. Homestead; watermelon (Citrullus lanatus (Thunb.) Matsum. \& Nakai var. Lanatus) cv. Sugar Baby; and white lupine (Lupinus albus L.) as test plants. Tissue infected with the Sesbania virus was ground in $0.025 \mathrm{M}$ phosphate buffer, $\mathrm{pH} 7.2$, containing $1 \%$ celite. The inoculum was applied to leaves of healthy plants dusted with 600 grit Carborundum. Symptoms were recorded 7 to 10 days after inoculation.

Seed transmission. Seeds (150, from the same seed lot of Sesbania speciosa as 


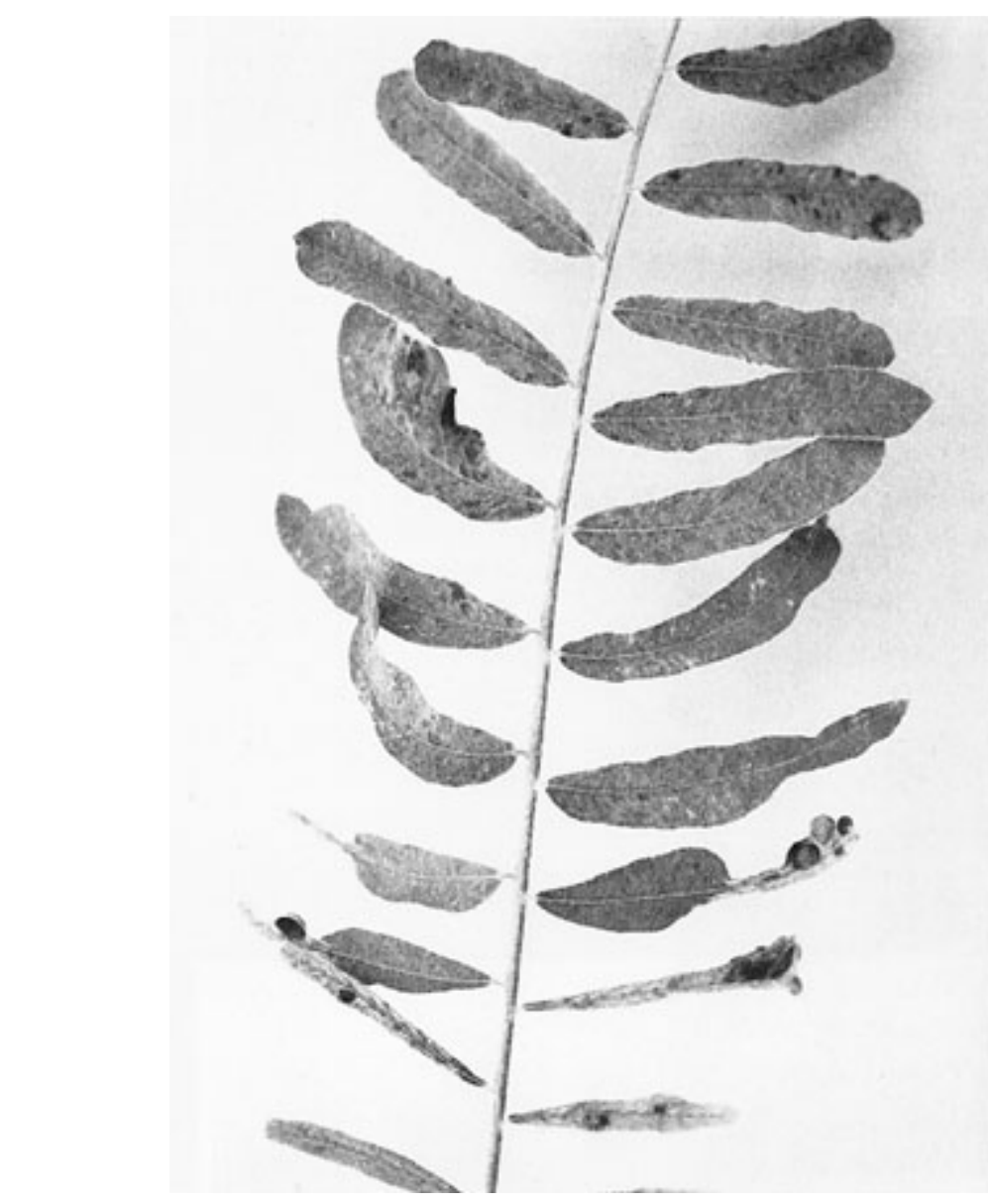

Fig. 1. Foliar symptoms of Sesbania virus in infected Sesbania speciosa in the greenhouse. Symptoms include distortion and enations, especially in portion closest to the stem, and mosaic toward the tip.

Table 1. Host range and host reaction of Sesbania virus

\begin{tabular}{|c|c|c|c|}
\hline \multirow[b]{2}{*}{ Hosts tested $^{a}$} & \multicolumn{3}{|c|}{ Host responses to inoculation ${ }^{b}$} \\
\hline & Sesbania virus & PMV $^{c}$ & BYMV $(\text { comparison })^{d}$ \\
\hline Green bean 1 & -/Vb, Di & -/Mo, St, Di & \\
\hline Green bean 2 & $-/ \mathrm{Mo}$ & $\mathrm{Vn} / \mathrm{Mo}, \mathrm{St}$ & $\mathrm{cLL} / \mathrm{Mo}, \mathrm{St}$ \\
\hline Green bean 3 & $-/ \mathrm{Mo}, \mathrm{Vc}$ & $\mathrm{Chl} / \mathrm{Mo}, \mathrm{Di}$ & cLL/ChlS \\
\hline Green bean 4 & -/ChlS, Mo & -/Vn, Tpn & $1 / \mathrm{ChlS}$ \\
\hline Green bean 5 & $-/ \mathrm{Mo}$, ChlS & $\mathrm{Vn} / \mathrm{Di}, \mathrm{Vn}, \mathrm{Mo}$ & \\
\hline Pea 1 & $-/ \mathrm{Mo}$ & $-1-$ & $-1-$ \\
\hline Soybean 1 & $-/$ Mo & $-/ \mathrm{Mo}$ & $\ldots$ \\
\hline Soybean 2 & $-/ \mathrm{Mo}$ & $-1-$ & $-/ \mathrm{Mo}$ \\
\hline \multicolumn{4}{|c|}{ Tobacco \& wild species } \\
\hline N. tabacum 1 & $-1-$ & $\ldots$ & 1/- \\
\hline N. tabacum 2 & $-1-$ & $\ldots$ & $1 /-$ \\
\hline N. benthamiana 1 & $-/ \mathrm{Mo}$ & -/Mo, Di & -/Mo, Di \\
\hline N. benthamiana 2 & -/Mo & -/Mo, Di & -/Mo, Di \\
\hline White lupine & $-/ \mathrm{Mo}$ & $-/ \mathrm{Mo}, \mathrm{Di}, \mathrm{n}$ & $-/ M o, D i, n$ \\
\hline
\end{tabular}

${ }^{a}$ Green bean $1=$ cv. Top Crop, 2 = Black Turtle 2, 3 = Bountiful, $4=$ Pinto, and $5=$ Black Turtle Soup; pea $1=\mathrm{cv}$. Perfected Wales; soybean $1=\mathrm{cv}$. Tracy $\mathrm{M}$ and $2=$ Bragg; Nicotiana tabacum $1=$ cv. NC 95 and $2=$ Burley 21; N. benthamiana $1=\mathrm{cv}$. TW 16 and $2=$ TW 17. Plants tested but showing no symptoms: Cucumber cv. Chicago Pickling; cowpea $1=\mathrm{cv}$. California Blackeye 5 and 2 = Coronet; eggplant cv. Black Beauty; lima bean cv. Henderson; pea $2=$ Dark Skin Perfection, and 3 = Little Marvel; peanuts $1=\mathrm{cv}$. Georgia Red and $2=$ Florunner; pepper cv. Hot Hungarian; pumpkin cv. Early Sugar; squash cv. Early Golden Summer; N. glutinosa $1=$ cv. TW 58 and $2=$ TW 59; tomato cv. Homestead; watermelon cv. Sugar Baby.

${ }^{\mathrm{b}}$ Host response: $-/-=$ no symptoms on inoculated/noninoculated leaves; ChlS = chlorotic spots; Chl $=$ chlorosis; $\mathrm{cLL}=$ chlorotic local lesions; $\mathrm{Di}=$ distortion of leaves, crinkle, rugose, and so on; $1=$ latent, local; $\mathrm{Mo}=$ mosaic or mottle; $\mathrm{n}=$ necrosis; $\mathrm{s}=$ systemic latent (determined by enzymelinked immunosorbent assay); $\mathrm{St}=$ stunt; $\mathrm{Tpn}=$ top necrosis; $\mathrm{Vb}=$ vein banding; $\mathrm{Vc}=$ vein clearing; $\mathrm{Vn}=$ vein necrosis; $\ldots$ indicates that this host was not tested against this virus.

${ }^{c}$ Bean yellow mosaic potyvirus pea strain (pea mosaic virus) PV 89.

${ }^{\mathrm{d}}$ Bean yellow mosaic virus reactions based upon published results used here for comparison. that used to plant the regeneration plot from which the virus was collected) were planted in an insect-proof greenhouse away from any infected plants. Seedlings were observed for the presence of symptoms for 4 weeks and plants were tested by direct antigen coating-ELISA with PTY1 monoclonal antiserum.

Polyclonal antisera-based ELISA. The sources of the polyclonal antisera used were as follows (dilutions are indicated in parentheses): ATCC supplied BYMV $(1: 5,000)$ PVAS-368; O. W. Barnett, Clemson University, Clemson, South Carolina, donated clover yellow vein potyvirus (CYVV; 1:6,000), cowpea mosaic comovirus (CPMV; 1:10,000), cowpea severe mosaic comovirus (CSMV; 1:10,000), cucumber mosaic cucumovirus (CMV; 1:4,000), PMV (1:4,000), and southern bean mosaic sobemovirus (SBMV; 1:10,000); R. O. Hampton, Corvallis, Oregon, donated cowpea aphid-borne mosaic potyvirus (CABMV; $1: 2,000$ ), bean mild mosaic carmovirus (for detection of cowpea mottle carmovirus; 1:500), and white lupine mosaic potyvirus (WLMV; 1:10,000); H. J. Vetten, Braunschweig, Germany donated cowpea mild mottle carlavirus (CMMV; 1:10,000); and J. W. Demski donated blackeye cowpea mosaic potyvirus (B1CMV; 1:500), PeMV (1:750), and peanut stripe potyvirus (PStV; 1:500). In preliminary tests, the general potyvirus monoclonal antibody PTY 1 (1:200), from Agdia Inc., Elkhart, Indiana, and the monoclonal tomato spotted wilt tospovirus (TSWV) antibody (1:600), from J. L. Sherwood, Stillwater, Oklahoma, were also employed.

For viral assays by double antibody sandwich-ELISA, infected and healthy leaf tissue was triturated at a 1:10 dilution $(\mathrm{wt} / \mathrm{vol})$ in antigen buffer $(0.04 \mathrm{M}$ $\mathrm{KH}_{2} \mathrm{PO}_{4}, 0.46 \mathrm{M} \mathrm{Na}_{2} \mathrm{HPO}_{4}, 0.14 \mathrm{M} \mathrm{NaCl}$, $0.003 \mathrm{M} \mathrm{NaN}, 0.003 \mathrm{M} \mathrm{KCl}, 0.05 \%$ [vol/vol] Tween 20, pH 7.5) $(4,14)$. The viruses for which this procedure was used were BlCMV, PeMV, PStV, and TSWV. Plates were coated with purified immunoglobulin $\mathrm{G}$ at the above dilutions and the antibody-conjugates were used at the same dilutions.

For viral assays by antigen coated plate (ACP)-ELISA, infected or healthy leaf tissue was triturated at a 1:10 dilution (wt/vol) in extraction buffer $(0.15 \mathrm{M} \mathrm{NaCl}$, $0.036 \mathrm{M} \mathrm{Na}_{2} \mathrm{HPO}_{4}, 0.016 \mathrm{M} \mathrm{NaH} \mathrm{PO}_{4}$, $0.013 \mathrm{M}$ sodium diethyldithiocarbamate, $0.003 \mathrm{M} \mathrm{NaN}_{3}, \mathrm{pH} \mathrm{7.1)}$ (5) and further diluted to a final dilution of 1:100 in this buffer. These extracts were placed into duplicate wells per sample, and incubated overnight at $4^{\circ} \mathrm{C}$. Polyclonal rabbit antisera, used at their respective dilutions in healthy plant extract (1:50 wt/vol healthy cowpea tissue and conjugate buffer), were added to microtiter plates and incubated at $37^{\circ} \mathrm{C}$ for $1.5 \mathrm{~h}$. Secondary antibody, goat anti-rabbit antibody conjugated to alkaline phosphatase at 1:1,500 dilution, was added 
to plates and incubated for $1.5 \mathrm{~h}$ at $37^{\circ} \mathrm{C}$. Secondary antibody for the detection of bound monoclonal antibodies in the preliminary tests was goat anti-mouse antibody conjugated to alkaline phosphatase at 1:1,500 dilution. After incubations of plant extracts, antisera, and conjugates, plates were washed three times in phosphate buffered saline-Tween, $\mathrm{pH} 7.5$ (14). After a final washing, the plates received alkaline phosphatase substrate

Table 2. Comparison of polyclonal antisera ELISA values ${ }^{\mathrm{a}}$ produced by extracts from infected plants with bean yellow mosaic virus subgroup of potyviruses

\begin{tabular}{lccc}
\hline & \multicolumn{3}{c}{ Antisera $^{\mathbf{c}}$} \\
\cline { 2 - 3 } Virus $^{\mathbf{b}}$ & BYMV & WLMV & PMV \\
\hline Sesbania virus & 0.353 & 0.231 & 0.255 \\
BYMV & 0.538 & 0.379 & 0.368 \\
PMV & 0.081 & 0.021 & 0.142 \\
CYVV & 0.031 & 0.035 & 0.008 \\
Healthy bean & 0.001 & 0.017 & 0.029 \\
\hline
\end{tabular}

a Average $A_{405}$ values from duplicate wells after 2-h substrate incubation. Used standard antigen coated plate-enzyme-linked immunosorbent assay procedures.

b Sesbania virus = virus isolated from Sesbania speciosa; $\mathrm{BYMV}=$ bean yellow mosaic virus (PV-368); $\mathrm{PMV}=$ pea mosaic virus $(\mathrm{PV}-89)$; $\mathrm{CYVV}=$ clover yellow vein virus $(\mathrm{J}$. W. Demski); healthy bean $=$ Phaseolus vulgaris . All samples from fresh bean plants except CYVV, which was taken from freeze-dried tissue.

${ }^{\mathrm{c}} \mathrm{BYMV}=$ bean yellow mosaic virus polyclonal antiserum (PVAS-268); WLMV = white lupine mosaic virus (R. O. Hampton); $\mathrm{PMV}=$ pea mosaic virus polyclonal antiserum (O. W. Barnett). and were incubated at room temperature for 1 to $2 \mathrm{~h}$. The absorption $\left(A_{405}\right)$ values of generated p-nitrophenol were recorded on a Dynatech MR 700 plate reader. Assays were considered positive when sample absorption values exceeded the mean value for healthy controls plus 2.5 times the standard deviation among wells containing controls.

Monoclonal antibody-based ELISAs. Potyvirus isolates. Purified preparations of potato virus Y (PVY 3), pepper mottle virus (PepMoV NC165), tobacco etch virus (TEV PV69), BYMV GDD (PV-368), BCMV, papaya ringspot virus (PRSV), and watermelon mosaic virus (WMV), as well as BYMV- and PVY C-infected $N$. benthamiana, PVY 3-infected potato, and TEV PV-69-infected N. tabacum cv. Burley 21 were prepared as described previously (10).

Virus purification. The Sesbania virus was purified by a protocol based on that published by Hammond and Lawson (7). This purified virus was then ready for use in the monoclonal antibody panel tests described next.

Monoclonal antibodies. Twenty-six MAbs from a previous study (10), designated "PTY" MAbs, were used to compare the isolated potyvirus to other characterized potyviruses. Members of this panel of MAbs recognize epitopes that are (i) specific to BYMV strains, (ii) common to members of the BYMV subgroup, (iii) distinctive for unique potyviruses, or (iv) common to many distinct potyviruses $(6,8-10)$.

ACP-ELISA. Purified virus or plant sap extracts were evaluated using the PTY MAbs in an indirect ACP-ELISA as de- scribed (10). Plant samples were prepared as described (10), except that the $0.05 \mathrm{M}$ sodium carbonate-bicarbonate coating buffer (CB), pH 9.6, with $2 \%$ polyvinylpyrrolidone (PVP) extraction buffer also contained $0.2 \%$ sodium diethyldithiocarbamate (DIECA). Purified viruses were diluted to $2 \mu \mathrm{g} / \mathrm{ml}$ in $\mathrm{CB}$ and dispensed to duplicate wells of Nunc MaxiSorp polystyrene ELISA plates.

\section{RESULTS AND DISCUSSION}

Samples of the infected $S$. speciosa plants were collected from the regeneration plot for testing. Mosaic, leaf distortion, and leaf enations were present in infected $S$. speciosa plants growing in the greenhouse (Fig. 1). In preliminary serological tests, infected tissues revealed a strong positive reaction with the general potyvirus monoclonal antibody PTY 1 by ACP-ELISA (10). No reactions were obtained with antisera of BlCMV, CABMV, PeMV, PStV, soybean mosaic potyvirus, lettuce mosaic potyvirus, turnip mosaic potyvirus, or any of the non-potyvirus legume viruses tested, nor with the TSWV MAb.

In the host range test (Table 1), the virus produced mild or moderate mosaic symptoms on green bean cvs. Black Turtle 2, Bountiful, and Pinto; white lupine; and pea cv. Perfected Wales. Perfected Wales is immune to BYMV and PMV and produces a necrotic reaction to WLMV. The symptoms produced on white lupine by these three viruses are much more severe. The more severe symptoms produced on the three bean cultivars, especially Pinto, by PMV also differ from the Sesbania virus. The lack of infection of $N$. tabacum by the

Table 3. Differentiation of purified potyviruses in antigen-coated plate enzyme-linked immunosorbent assay (ELISA) by a monoclonal antibody panel ${ }^{\mathrm{a}}$

\begin{tabular}{|c|c|c|c|c|c|c|c|c|}
\hline \multirow[b]{2}{*}{ Monoclonal antibody ${ }^{b}$} & \multicolumn{8}{|c|}{ ELISA $A_{405}$ values for 8 viruses ${ }^{c}$} \\
\hline & Sesbania virus & WLMV & PMV PV 89 & BYMV GDD & BYMV G & CYVV Pratt & PepMoV NC 165 & TEV NAT \\
\hline PTY 1 & $+++^{d}$ & +++ & +++ & +++ & +++ & +++ & +++ & +++ \\
\hline PTY 2 & - & +++ & +++ & +++ & +++ & +++ & - & +++ \\
\hline PTY 3 & - & ++ & +++ & ++ & +++ & ++ & ++ & - \\
\hline PTY 4 & ++ & ++ & +++ & ++ & +++ & ++ & + & - \\
\hline PTY 5 & - & - & ++ & ++ & ++ & + & - & ++ \\
\hline PTY 8 & + & + & + & + & +++ & + & - & ++ \\
\hline PTY 9 & - & - & + & + & ++ & + & + & ++ \\
\hline PTY 10 & - & - & - & - & - & - & +++ & +++ \\
\hline PTY 11 & ++ & + & ++ & ++ & ++ & + & - & + \\
\hline PTY 13 & + & +++ & ++ & +++ & +++ & ++ & - & - \\
\hline PTY 14 & +++ & +++ & ++ & +++ & +++ & ++ & - & - \\
\hline PTY 17 & +++ & - & +++ & ++ & +++ & ++ & - & - \\
\hline PTY 18 & ++ & - & + & ++ & +++ & ++ & - & - \\
\hline PTY 19 & ++ & ++ & - & ++ & ++ & + & - & - \\
\hline PTY 21 & - & + & - & +++ & +++ & - & + & - \\
\hline PTY 24 & - & - & - & +++ & +++ & - & - & - \\
\hline PTY 33 & - & + & - & +++ & +++ & - & + & - \\
\hline PTY 35 & - & - & - & +++ & +++ & - & - & - \\
\hline PTY 43 & - & ++ & - & +++ & - & - & - & - \\
\hline
\end{tabular}

a Indirect ELISA using $\approx 2 \mu \mathrm{g} / \mathrm{ml}$ purified potyvirus dissociated with $0.2 \%$ SDS at $56^{\circ} \mathrm{C}, 10$ min prior to dilution in coating buffer and direct coating of Nunc Maxisorp ELISA plate.

b Potyvirus monoclonal antibody panel as described by Jordan and Hammond (8).

c Sesbania virus described in this article, WLMV = white lupin mosaic potyvirus, PMV-PV89 = pea mosaic potyvirus, BYMV-GDD and BYMV-G = bean yellow mosaic potyvirus isolates, CYVV-Pratt $=$ clover yellow vein potyvirus, PepMoV-NC165 = pepper mottle potyvirus, TEV-NAT $=$ tobacco etch potyvirus.

d Relative ELISA $A_{405}$ values ( 1 to 3 h substrate incubation) $=+++=A_{405}$ greater than $1.2 ;++=A_{405}$ of 0.6 to $1.2 ;+=A_{405}$ of 0.2 to $0.6 ;-=A_{405}$ less than 0.2 . 
Sesbania virus is also dissimilar to BYMV and CYVV, and the latent infection of $N$. benthamiana differs from the mosaic produced on this host by BYMV and PMV. $S$. speciosa inoculated with PMV and the virus isolated from Sesbania produced identical symptoms, but the evidence from the host range data may indicate a distinct virus. Since these data came from only two repetitions, the differences may be too slight to support the existence of a unique virus without further information.

Potyvirus-like particles were observed by electron microscopy in negatively stained preparations of leaves infected with the seedborne isolate from Sesbania.

A quarantine greenhouse test in which 150 seeds were planted from the same seed lot as the field plot row yielded one plant with the same symptoms as plants from the field $(0.6 \%)$. This plant tested positive in ACP-ELISA with the general potyvirus monoclonal antibody PTY 1. Although there were not enough seeds tested for an accurate determination of the rate of transmission, it may be concluded from this test that the virus is seed-transmitted. Bos (2) noted that BYMV and PMV are seed transmitted at a low rate of 0 to $6 \%$, depending upon the host plant and the age of the mother plants when they became infected. The low rate of transmission with the Sesbania virus fits into this range. Viruses in the BCMV subgroup may obtain seed transmission rates as high as $83 \%$ (12).

The preceding data indicated the need for additional serological studies to further characterize this virus. Additional ELISA tests produced positive reactions with BYMV, PMV, and WLMV antisera, which suggested the Sesbania virus was either BYMV or at least in that subgroup (Table 2). The WLMV antiserum had been reported to react strongly with BYMV and PMV and weakly against clover yellow vein potyvirus (CYVV; 8). However, our tests indicated a weak reaction with PMV as well. Strains of these viruses (BYMV, CYVV, PMV, and WLMV) are the described members of the BYMV subgroup $(8,9,11)$.

Jordan and Hammond (10) selected MAbs PTYs 1 to 12 and 19 to define specific epitopes for members of the potyvirus group. The BYMV subgroup epitopes are defined by PTYs 13, 14, 17, and 18. PTYs
21 and 33 react with epitopes of some isolates of BYMV and PMV, and PTYs 24, $30,35,37$, and 43 with other isolates of BYMV. The reactivities of the PTY MAbs against the Sesbania virus from leaf extracts and from purified virus (Table 3) occurred only with MAbs PTY 1, 4, 8, 11, $13,14,17,18$, and 19. These data indicate that the virus is a potyvirus and suggests that it is a member of the BYMV subgroup, but is not a strain of BYMV or of one of the described members of the subgroup.

Recent investigations of potyviruses and the BYMV subgroup $(8,9,11)$ clearly indicate that there are many potyviruses related to but distinct from BYMV, leading to confusion. For instance, McKern et al. (11) retrospectively suggested that WLMV (8) was probably a strain of BYMV. This identity seems unlikely, however, since resistance to WLMV was conferred exclusively by Pisum sativum gene $w l v$ (15), a gene discovered only by investigating WLMV-specific resistance sources. The Sesbania virus appears to be another example of the diversity of BYMV-like viruses. Accordingly, we avoid any inference that the Sesbania virus is a strain of BYMV. Sequence analysis of the $3^{\prime}$ noncoding and coat protein regions of the Sesbania virus, as well as WLMV, (work in progress) should help determine the relationships. The potential importance of a seedborne BYMV-like virus in Sesbania is now a factor which must be considered in the acquisition and distribution of germ plasm because this virus could cause diseases in other important leguminous crops.

\section{ACKNOWLEDGMENTS}

We thank J. Hammond for helpful comments and suggestions during the performance of these tests; R. O. Hampton for helpful comments and suggestions during the preparation of the manuscript; O. W. Barnett, J. W. Demski, R. O. Hampton, J. L. Sherwood, and H. J. Vetten for supplying the antisera for the ELISA tests; M. A. Guaragna for technical assistance; M. Brannigan for her assistance with electron microscopy; and W. Bliss for testing our virus against soybean mosaic, lettuce mosaic, and turnip mosaic potyviruses.

\section{LITERATURE CITED}

1. Bhuvaneshwari, M., Subramanya, H. S., Gopinath, K., Savithri, H. S., Nayudu, M. V., and Murthy, M. R. N. 1995. Structure of sesbania mosaic virus at 3 A resolution. Structure (London) 3(10):1021-1030.
2. Bos, L. 1970. Bean yellow mosaic virus C.M.I./A.A.B. Descriptions of Plant Viruses No. 40.

3. Edwardson, J. R. 1974. Host ranges of viruses in the PVY-group. Page 225 in: Fla. Agric. Exp. Stn. Mono. Ser. No. 5.

4. Gillaspie, A. G., Jr., Hopkins, M. S., and Pinnow, D. L. 1993. Relationship of cowpea seed-part infection and seed transmission of blackeye cowpea mosaic potyvirus in cowpea. Plant Dis. 77:875-877.

5. Gillaspie, A. G., Jr., Hopkins, M. S., Pinnow, D. L., and Hampton, R. O. 1995. Seedborne viruses in preintroduction cowpea seed lots and establishment of virus-free accessions. Plant Dis. 79:388-391.

6. Hammond, J., Jordan, R. L., Larsen, R. C., and Moyer, J. W. 1992. Serological relationships among three filamentous viruses of sweet potato examined using polyclonal and monoclonal antibodies. Phytopathology 82:713-717.

7. Hammond, J., and Lawson, R. H. 1988. An improved purification procedure for preparing potyviruses and cytoplasmic inclusions from the same tissue. J. Virol. Methods 20:203217.

8. Hampton, R. O., Shukla, D. D., and Jordan, R. L. 1992. Comparative potyvirus host range, serology, and coat protein peptide profiles of white lupin mosaic virus. Phytopathology 82:566-571.

9. Jordan, R. 1992. Potyviruses, monoclonal antibodies, and antigenic sites. Arch. Virol. Suppl. 5:81-95.

10. Jordan, R. L., and Hammond, J. 1991. Comparison and differentiation of potyvirus isolates and identification of strain-, virus-, subgroup-specific, and potyvirus group-common epitopes using monoclonal antibodies. J. Gen. Virol. 72:25-36.

11. McKern, N. M., Barnett, O. W., Whittaker, L. A., Mishra, A., Strike, P. M., Xiao, X. W., Ward, C. W., and Shukla, D. D. 1993. Sequence relationships among the coat proteins of strains of pea mosaic, white lupin mosaic, and bean yellow mosaic potyviruses. Phytopathology 83:355-361.

12. Morales, F. J., and Bos, L. 1988. Bean common mosaic virus. A.A.B. Descriptions of Plant Viruses No. 337.

13. Morris, J. B. 1997. Special-purpose legume genetic resources conserved for agricultural, industrial, and pharmaceutical use. Econ. Bot. 51:251-263.

14. Pinnow, D. L., Chalkley, J. H., and Demski, J. W. 1990. A practical method for the detection of peanut stripe virus in peanut seed. Ga. Agric. Exp. Stn. Res. Rep. 584.

15. Provvidenti, R., and Hampton, R. O. 1993. Inheritance of resistance to white lupin mosaic virus in common pea. HortScience 28:836-837.

16. Sreenivasulu, P., and Nayudu, M. V. 1982. Purification and partial characterization of Sesbania mosaic virus. Curr. Sci. 51:8687 